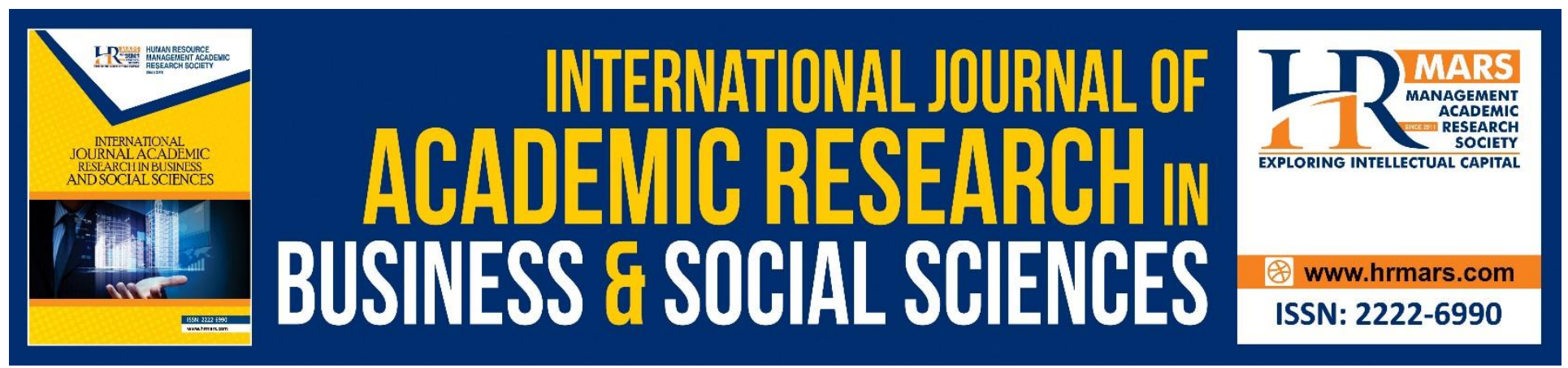

\title{
Literature Review on Theravada Siamese Buddhism's Mediation Practice in Kelantan, Malaysia
}

Akila Mamat, M.Safri Ali, Syed Hadzrullathfi Syed Omar, Zaida Zainal Abidin, Mohd Hasrul Shuhari, Aminudin Basir @ Ahmad, Shumsudin Yabi.

To Link this Article: http://dx.doi.org/10.6007/IJARBSS/v9-i5/5899 DOI: 10.6007/IJARBSS/v9-i5/5899

Received: 13 March 2019, Revised: 22 April 2019, Accepted: 07 May 2019

Published Online: 28 May 2019

In-Text Citation: (Mamat et al., 2019)

To Cite this Article: Mamat, A., Ali, M. S., Omar, S. H. S., Abidin, Z. Z., Shuhari, M. H., Ahmad, A. B. @, \& Yabi, S. (2019). Literature Review on Theravada Siamese Buddhism's Mediation Practice in Kelantan, Malaysia.

International Journal of Academic Research in Business and Social Sciences, 9(5), 508-517.

Copyright: (c) 2019 The Author(s)

Published by Human Resource Management Academic Research Society (www.hrmars.com)

This article is published under the Creative Commons Attribution (CC BY 4.0) license. Anyone may reproduce, distribute, translate and create derivative works of this article (for both commercial and non-commercial purposes), subject to full attribution to the original publication and authors. The full terms of this license may be seen at: $\underline{\text { http://creativecommons.org/licences/by/4.0/legalcode }}$

Vol. 9, No. 5, 2019, Pg. 508 - 517

http://hrmars.com/index.php/pages/detail/IJARBSS

JOURNAL HOMEPAGE

Full Terms \& Conditions of access and use can be found at http://hrmars.com/index.php/pages/detail/publication-ethics 


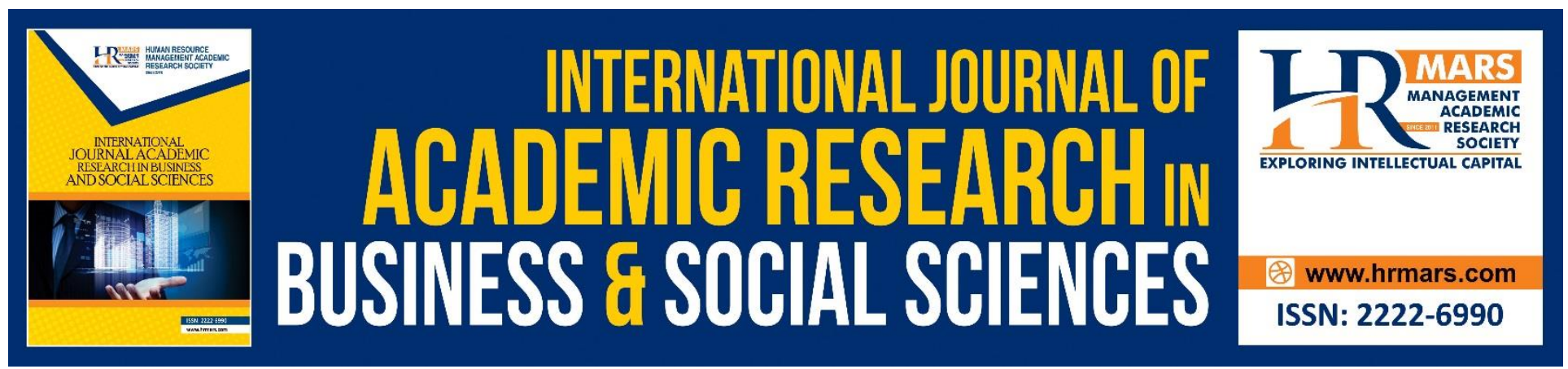

\title{
Literature Review on Theravada Siamese Buddhism's Mediation Practice in Kelantan, Malaysia
}

\author{
Akila Mamat, M.Safri Ali, Syed Hadzrullathfi Syed Omar, Zaida \\ Zainal Abidin, Mohd Hasrul Shuhari, Aminudin Basir @ Ahmad, \\ Shumsudin Yabi \\ Universiti Sultan Zainal Abidin (UniSZA),Kampus Gong Badak,21300, Kuala Nerus, Terengganu, \\ Malaysia \\ Corresponding Author Email: akila@unisza.edu.my
}

\begin{abstract}
Meditation is one of the practices in Buddhism that is oriented based on the reason to form, control and train the mind to face, accept and manage things or problems in our lives, so that we can remain calm and patience. In Kelantan, the Siamese, which is the minority ethnic, who believe in Theravada Buddhism practice the meditation. Therefore, this study presents three objectives that is purposed to explain and elaborate the meditation practice in detail. The objectives are to explain the history of the arrival of Buddhism in Kelantan, to clarify the concept of meditation in Buddhism's teachings, and to identify the concept of meditation based on Theravada, one of the schools of Buddhism, in Kelantan. In carrying out this study, the researcher implements the content analysis method to examine the observed literature review. The researcher also employs library research to gather the data. This study found that the meditation practice among the Theravada Buddhist in Kelantan is dominated by the Siamese who is originated from Thailand. While, the form, the way and the objective of meditation that is practiced there is to appreciate the teachings of Buddhism, Dhamma and Sangha such as Sila and Atthasila in the concept of Four Noble Truth and Noble Eightfold Path to achieve the eternal happiness, and to become a true Bikkhu (Arahat) and to honour the Three Jewels of Buddhism.
\end{abstract}

Keywords: Meditation, Four Noble Truth, Noble Eightfold Path, true Bikkhu, Three Jewels of Buddhism.

\section{Introduction}

Malaysia is very well-known with its diversity of religious, ideologies and cultures as it is inhabited by various races, tribes, ethnics such as Malays, the orang Asli (indigenous people), Chinese, Indians, Kadazans, Bidayuh and many more. Malaysians have different believes, religions and cultures based 
on their races and ethnics. Thus, the knowledge of religious and cultural differences should be taken proactive by all members of society to create and maintain the harmony, tolerance and mutual respect. For that purpose, the researcher chose meditation practice practiced by the Theravada Buddhist in Kelantan to be thoroughly studied that consist of the history of the arrival of Buddhism in Kelantan, the clarification of the concept of meditation according to Buddhism's teachings and also the meditation practices among the Theravada Buddhist in Kelantan

\section{History of the Arrival of Buddhism in Kelantan}

Sivachandralingam and Ayadurai (2005:45) explain the history of the arrival of Buddhism in Kelantan in their work entitled Tamadun Dunia, which they state that Buddhism came to Malay Peninsula because it is one of the famous place for traders and immigrants to stopover and live especially those who are from India, Arab and China because the Malay Peninsula, geographically, is a very strategic place. Among the states that have entrepot ports is Kelantan, Terengganu, Pahang, Kedah, Selangor, Johore, Singapore and Malacca.

According to Darussalam (2001: 165) in his work Tamadun Islam dan Tamadun Asia, the arrival of the immigrants has influenced the locals' thoughts, ideologies and cultures, such as the Buddhism. Buddhism is one of the earliest religions arrived in the Malat world and Southeast Asia. Therefore, Buddhism became popular and followed by the locals who believed in animism at that time.

Furthermore, Majumdar (1974: 109) does not deny some opinions that state that Buddhism existed in Southeast Asia nowadays is the result of the conquest of the emperor of India during the dynasty of Mauriya named Emperor Asoka. He is also known as Devanampiya Piyadasi. He has appointed Mahendra and Sanghamitra as his representatives to spread and teach Buddhism in Southeast Asia, Sri Lanka, Western Asia, Egypt and Eastern Europe.

Regarding the date of the admittance of Buddhism in Malaysia, Hart (2006:25) state that, Buddhism came into the Malay Peninsula in the third century B.C. when Asoka, the Emperor of India who believes in Buddhism, send two bikkhu named Ven Sona and Ven Uttara as his representative to Southeast Asia and the Malay Archipelago to spread the Buddhism's teachings. As the result of his action, Buddhism growing firmly in the fifth century.

Meanwhile, Dhammananda (2000: 25) through his book, How to Practice Buddhism, states that the existence of Buddhism in Malaysia can be proved through the existence of the culture, celebrations, places of worship, monuments, and Buddhism's sculpture in several places in Malaysia. In addition, John Anderson (2013:73) says that Buddhism exists in Kelantan since 1350 AD when the Siamese Ayudha empire has overthrew the older Siamese rulers and conquered several states in the Malay Peninsula to be their centre of government. Therefore, these situations illustrated that Siamese has been settled in the Malay Peninsula.

Next, Coedes (1968: 2014) in his research entitled The Indianized States of Southeast Asia, proves that Buddhism was transferred to Kelantan by the Siamese since the $13^{\text {th }}$ and $14^{\text {th }}$ century AD, 
and they formed their own community peacefully and harmony without any disturbance from the locals. Since then, they, the Buddhism community, has grown from time to time with various facilities and privileges provided such as the two places of worship, Wat Machimmaran and Wat Photiviharn, situated in their community. Ismail (1996: 2) has verified that Siamese Buddhist communities in Kelantan existed a long time ago since Wat Phothiviharn was built 300 years ago.

Based on the researches about the history of Buddhism in Kelantan stated before, we can conclude that Buddhism exists in Kelantan since 300 years ago as the impact of the spread movement of Buddhism in Asia proposed by Emperor Asoka from the dynasty of Mauriya based in India. Buddhism was spread in Kelantan through the Siamese community who immigrated into Kelantan and their number grew larger through times. They have also built several places of worship, which are very active in organizing various activities.

\section{Explanation of the Concept of Meditation according To Buddhism's Teachings}

In the aspect of Buddhist meditation practice, researchers have focused on some important elements including introduction, form, function and benefits. For example, regarding the introduction of meditation, Krishnanda (2003: 212) and Singh (1994: 180) have agreed that the term of meditation is taken from the meditation word derived from Latin origin. Meditation is an act that illustrates the act of reflection, training and thinking.

Then, according to Udupa (1978: 162) in a study titled Stress and It's Management by Yoga, meditation is a traditional knowledge that talks about coordination of body, soul and mind to be at their best so that a person is able to handle psychological or physical problems that arise.

Wise (2002: 9) also emphasizes in her book Awakening the Mind: A Guide to Mastering the Power of Your Brain Waves, meditation is an act that emphasizes the state of a specific consciousness and not just ways of using some sort of techniques. Thus, if one wants to do meditation, must first identify the condition of themselves and should be guided by trained and experienced teachers so that the participant understand the meditation needs and the suitability of a method that ought to be use.

Sayahaw (2016: 4) also agrees with the statement as mentioned in his research Manual of Insight. He adds, meditation is a state of mind that is calm from of things that is depressing and as the most effective function for curbing the intense desire for life (Tanha) which can cause people to get stuck with suffering (Dukkha). From the above explanation, clearly shows that meditation is a practice and training to clear the mind, get calm and avoiding suffering.

Furthermore Mahayasi (2016: 12) said, in Theravada Buddhism there are two forms of meditation which is Samadhi Bhavana dan Vipassana Bhavana. Samadhi Bhavana aims to achieve spiritual tranquillity and to achieve the goal of this type of meditation, one must to use a meditation object as a method of contemplation. Then, Dhammananda (2000: 288) said. Samadhi Bhavana as one of the psychological approaches to improve the training process and clarity of mind. 
Kamilah (2013: 2) also explains in her research titled Meditation in Buddhism, that Samadhi Bhavana is a mind-centered meditation, attention and focus. This type of meditation focuses on the object of meditation. This type of meditation is also intended to train the mind to work perfectly and to achieve calm. Therefore, Samadhi Bhavana is one of the ways to get a specific place of awareness.

Disputhera (2004: 52) added, Vipassana Bhavana type of meditation is a clear view meditation. A type of meditation that brings an explanation of the perfection of an object. This type of meditation usually focusing on physical objects first before achieving inner sanctity. So this kind of meditation emphasizes the form of thoughts and feelings when meditating to raise awareness (Citta).

Based on the study mentioned, Samadhi Bhavana type meditation emphasizes attention and focus to require peace of mind and Vipassana Bhavana is based on observation, development and purification in a person towards something. However, both are interrelated and complement each other because Samadhi Bhavana is used as a preparation for the Vipassana Bhavana type of meditation. Furthermore, a true observation can only be achieved by having a calm soul.

Relating to function in Theravada Buddhist meditation practice, Mahadevan (1974: 114) in his writing Invitation to Indian Philosophy, to understand and solve the problem, practitioners need to understand Four Noble Truth (Cattari Ariya Saccani) including Dukkha (The truth about the existence of Dukkha) Dukkha Samudaya (The truth about the cause of Dukkha), Dukkha Nirodha (the truth about the disappearance of Dukkha), and Dukkha Nirodha Gamini Patipada Magga (the truth about the eighth path towards the end of the Dukkha).

Narada (1998: 190) adds, meditation also helps practitioners to practice and appreciate the Eightfold Path of Noble Truth which is Samma Titi (Right Ideas), Samma Sangkapa (Right Intention), Samma Waja (Right Speech), Samma Kammanta (Right Achievement), Samma Asheva (Right Profession), Samma Vayam (Right Perseverance), Samma Sati (Right Caution) and Samma Samadhi (Right Meditation).

Regarding Mahadevan's (1974) and Narada (1998) views relating the function of meditation is to form the character, personality, desire and the spirit of the practitioner to be in good condition coincide with the recommendation in in the Eighth Path of Truth and the Four Noble Truths in Buddhism.

In addition, Buddhist meditation aims to achieve several goals. Among them is Antasara (1981: 215) mentions that one of the goal is to reach Nirvana because Nirvana is the ultimate goal in Buddhist meditation, getting eternal happiness after death and is regarded as a paradise dreamed by all such adherents. Furthermore, practitioners of meditation that have reached Nirvana will automatically achieve Panya which is the concentrated insight or the ultimate knowledge of the highest value. 
INTERNATIONAL JOURNAL OF ACADEMIC RESEARCH IN BUSINESS AND SOCIAL SCIENCES Vol. 9, No. 5, May, 2019, E-ISSN: 2222-6990 ㄷ 2019 HRMARS

Mahadevan (1974: 114) said, meditation practice can elevate the levels according to the level of practitioners' practice of meditation, which is Sotapanna, Sakadagami, Anagami and Arahat level. At Arahat level only one who gets enlightenment and doing meditation properly can achieve this level.

Furthermore, Kwee (2006: 144) in his writing titled Buddha: The Concept said, according to the doctrine of Anatta among the most important goals and achievements in meditation practice is when the practitioner has successfully acquired Vipassana enlightenment. That is a form of doctrine related to self-liberation. The main purpose of meditation also is to breaks away from punishment and bad torture (Karma) and to achieve true happiness known as Nirvana.

However, the most importantly according to Waramuni (1980: 80) in his study Bayna alBūdhiah Wa al-Nașrāniyyah Fì Ra'yinā, practitioners should submit their practice to Tri Ratna (Tiga Permata) iaitu Buddha sebagai penyebab terbentuknya agama Buddha, Dharma as the essence and content contained in the Buddha's teachings and and the Sangha as followers of religion consisting of ordinary members and sacred bikhhu who have reached the rank of Arahat.

For those who want perfect meditation, Crosby (2013: 36) states in Theravada Buddhism: Sustainability, Diversity and Identity, practitioners of meditation need to have strong will and intent to implement, understand and practice Sila Buddha well, having good physical and mental health, choose a quiet, silent and strategic meditation place without interference that can affect focus, set the right time and do not interfere with other tasks.

Meanwhile, Sayadaw (2007: 120) argues, there are also obstacles that meditation practitioners need to pass through. Among them, the disorder called Palibodha related to home, occupation and mystic powers. Shapiro (1984: 223) also said that there are other tests that need to be addressed by practitioners that are necessary such as need to sacrifice, be patient and not drift away with pleasure and success.

In this case, Masefield (2008: 37) mentions, to overcome all these obstacles, meditation practitioners need to identify the cause of the resistance, should avoid the source of the barrier and try to eliminate it because the barriers arise due to the behavior of the practitioner who is neglected when doing meditation that causes laziness, doubt, anxiety and loss of concentration.

Rahula (1959: 68) adds, Buddhist meditation activity is a positive activity that can stimulate the mind and body to be more eager to face various challenges in taking responsibility and task. Russell (2002: 49) emphasized, in order to gain effective meditation practice, candidates need to learn with experienced teachers. Furthermore, participants also need to follow individual discussions and teaching processes related to the participants' experience and understanding to identify the goals, expectations and appropriate meditation techniques for the participants. 
He (Rahula, 1959: 67) also stated that the purpose of meditation in the Buddha's teachings is not only good for the mind but also for the physical as well as the two elements are interconnected. Therefore, meditation practice needs to be done correctly, perfectly and with a calm mind so that it has a positive effect on the practitioner of meditation despite suffering from illness and physical inadequacy.

Blake (2012: 193) agrees with opinion that and says that meditation practice can activate enzymes that function as insulin supporter in the body to become more dominant, able to neutralize andrenaline effects, stabilize blood sugar content, prevent cholesterol from accumulating and protein damage in the body.

In general, meditation practices can help shaping the soul, good conduct and practitioner's life in line with the concepts and regulations recommended by the Buddha's teachings. Therefore, the practitioner can be a holy Bikkhu and is not bound by the existence of the world, attaining the eternal freedom and happiness found in the elements of Nibbana, Karma, Samsara, Nirvana and Panya as well as a sign of obedience, loyalty and respect for the Buddha, Dhamma and Sangha. Meditation practice can also contribute many benefits from various aspects to the life of practitioners of meditation, whether physically and spiritually.

\section{Meditation Practice in Thevarada Siamese Buddhists in Kelantan}

Kelantan is one of the states in the east of the Malaysia peninsula which is famous for its cultural beauty and nobility. It was recognized by Johnson (2012: 3) in his thesis titled The Buddha on Mecca's Varendah: Encounters, Mobilities and Histories along the Malaysian-Thai Border. According to him, although the state of Kelantan was governed by a conservative Islamic-ideological party until it was known as the state of Makkah, then the identity was reinforced when the Kelantan government declared the capital of Kelantan, Kota Bharu as the city of Islam in 2005. However, the strength of Islamic teachings in Kelantan does not put pressure on different religions there but respect the differences.

For example, some 'wat' (temples) have been established in Kelantan and are the pride of Buddhists there as places of worship, activities and gatherings (Chan, 2012: 6). The opinion was approved by Winzeler (1985: 103) in his thesis, Ethnic Relations in Kelantan: a Study of the Chinese and Thai as Ethnic Minorities in a Malaysia State. He said religious aspects need to be given their own rights and any race in building strengths and wealth among ethnic groups should not be allowed as it can undermine religious values in one's soul.

Regarding to the practice of meditation among the Thevarada Buddhists in Kelantan, Stokes (2000: 94) states, while practicing meditation (Samadhi) to train and enlighten minds, practitioners should also understand Cattari Ariyasaccani (Four Noble Truths) and Ariya Atthangiko Magga (Eight Truth Paths) contained in Panna (wisdom) which calls upon the right ideology and beliefs, while Sila (moral) invites the true conversation, deed and life to achieve happiness (Nirvana). 
According to Yong (1990: 18) in his study the role of Siam Biku in Wat Machi Maram, Jong Bakar village of Tumpat, Kelantan, the Buddhist Bikkhu in Kelantan serves as a reference to Buddhists who want to perform Buddhist religious rituals and meditation practice. The Bikkhu will also guide and demonstrate the correct meditative way for meditation participants so that the practice will be effective for participants. However, the Bikkhu there do not force meditators to follow all the rules of Buddhism and it is up to their choices.

The usual routine activities of Buddhists in Kelantan and also as a complement to the practice of meditation based on reports from Chian (1991: 57) in his study titled Religious Practice and Traditional Practice of the Thai Society at Kampung Terbok, Tumpat Kelantan was reading Paritta Pali and Namaskara. Among the different types of Paritta reads, are Vandana (Honor), Tisarana (Three Protection), Pancasila (Five Rule Sila), Buddhanussati (Contemplation of Buddha), Dhammanussati (Contemplation of the Dhamma) and Sanghanussati (Contemplation of the Sangha).

Paritta's recitation usually begins with the reading of Vandana (honor) and Tisarana (Three Protection), which is a greeting and seek protection from the Buddha, Dhamma and Sangha. The verse is read three times before a practice or ceremony to achieve confidence, clarity of mind and spirit to live a daily life. Examples of Vandana's speech include, Namo Tassa Bhagavato which means honoring him who is blessed. Paritta's recitation is also to commemorate the Sila of the Buddha's teachings in order to gain the noble character of Pancasila (Rule of Five Sila) and Atthasila (Rule of Eight Sila) (Desy, 2009: 27).

According to Williamson (2010: 188) in Transcendent in America: Hindu-Inspired Meditation Movements as New Religion, the Paritta mantra reading content in today's meditation ritual has been reduced to the smaller number of sentences so that reading becomes more concise and orderly meditation rituals are in line with the demands of the modern day and it will not take long.

From the discussion above, it is understood that the reading of Paritta Pali in Buddhist meditation is intended to recall the rules, prohibitions and disciplines in the teachings, such as Pancasila and Atthasila. Among the purposes of reading Paritta Pali is also to express loyalty and respect to Tri Ratna consisting of the Buddha, the Dhamma and the Sangha. Therefore, the Paritta Pali reading in Buddhist meditation encompasses all aspects of the Buddha's teaching.

On the practice of Namaskara, Buddhakhitta (1985: 19) explains, the practice refers to the act of worship (bow) three times before the Buddha statue during meditation. This practice is to bring honor and obedience to the Buddha, Dhamma and Sangha. Namaskara's practice will be more complete if accompanied by the practice of listening to the preach on the Dhamma rules describing the law and the true nature of Buddhism. The discussion is the highest demand in Buddhist teachings because it is knowledge that includes the mind, the human soul and the universe.

However, Mokhtar (1995: 103) argued in his study of Darma's Work: Humanity in Development, that the strength and continuity of the Buddha's teachings carrying out their religious 
INTERNATIONAL JOURNAL OF ACADEMIC RESEARCH IN BUSINESS AND SOCIAL SCIENCES Vol. 9, No. 5, May, 2019, E-ISSN: 2222-6990 @ 2019 HRMARS

activities at the Buddhist's wat in Kelantan also relied on their close ties with the Buddhist Sangha association in Thailand as an example of a more systematic and larger Buddhist organization.

The findings from the above study can be summarized that meditation practice has the most important place in the teachings of Theravada Buddha in Kelantan. This can be observed through the beliefs of those who consider meditation and complementary elements such as Paritta's and Namaskara's reading as the primary path to attaining the light of truth, the savior of misery, the preparation to solve the problems that arise in life and to understand the existence of something.

\section{Conclusion}

In general, Buddhism has existed in Kelantan since 300 years ago during the process of immigration from Thailand to Kelantan. The Buddha's Meditation practiced by the Theravada Buddhists in Kelantan was aimed at understanding the essence, guidance and restrictions contained in the elements of Sila, Phaliboda, Nivarana, Four Noble Truths, Eight Truth Paths, Paritta and Namaskara readings aimed at achieving success, happiness and freedom in the element Arahat, Nirvana and Panya.

\section{Acknowledgement}

We express our deepest gratitude to the Centre for Research Management, Innovation \& Commercialization (RMIC) as well as Faculty of Islamic Contemporary Studies, Universiti Sultan Zainal Abidin, Terengganu, Malaysia for supporting the publication of this article

\section{Reference}

Buddhakhitta, A. (1985). The Dhammapada: Buddha's Path of Wisdom. Sri Lanka: Buddhist Publication Society Kandy.

Wise, A. (2002). Awakening the Mind: A Guide to Mastering the Power of Your Brain Waves. California: Jeremy P.Tarcher/ Putnam.

Coedes, G. (1968). The Indianized States of Southeast Asia. Kuala Lumpur: University of Malaya.

Darussalam, G. (2001). Tamadun Islam dan Tamadun Asia. Kuala Lumpur: Utusan Publication \& Distributor Snd Bhd.

Stokes, G. (2000). Gillian Stokes. (2000). Buddha a Beginner's Guide. London: Hodder \& Stoughton.

Singh, I. (1994). Planned Attack on Aad Sri Guru Granth Sahib: Academics for Bleshemy. Chandigarh: International Centre of Sikh Studies.

Johnson, I. C. (2012). The Buddha on Mecca's Varendah: Encounters, Mobilities and Histories Along Malaysian-Thai Border. Washington: University of Washington Press.

Anderson, J. (2013). English Intercourse with Siam in the Seventeenth Century. New York: Routlegde. Udupa, K. N. (1978). Stress and It's Management by Yoga. New Delhi: Motilal Banarsidas.

Dhammananda, K. S. (2000). How to Practice Bhuddhism. Kuala Lumpur: Susana Abhiwurdhi Wardhana Society.

Mukti, K. W. (2003). Wacana Buddha Dharma. Jakarta: Yayasan Pembangunan Dharma.

Sayadaw, L. (2007). The Requisites of The Enlightenment: Bodhipakkhiya Dipani. Sri Lanka: Buddhist Publication Society. 
INTERNATIONAL JOURNAL OF ACADEMIC RESEARCH IN BUSINESS AND SOCIAL SCIENCES

Vol. 9, No. 5, May, 2019, E-ISSN: 2222-6990 @ 2019 HRMARS

Yong, L. S. (1990). Peranan Biku Siam di Wat Machi Maram, Kampung Jong Bakar Tumpat, Kelantan. Selangor: Universiti Kebangsaan Malaysia.

Chian, L. L. (1991). Amalan Keagamaan dan Amalan Tradisi Masyarakat Thai di Kampung Terbok, Tumpat Kelantan. Kuala Lumpur: Universiti Malaya.

Williamson, L. (2010). Transcendent in America: Hindu-Inspired Meditation Movements as New Religion. New York: New York University Press.

Sayadaw, M. (2016). Manual of Insight. New York: Simon and Schuster.

Eliade, M. (1987). The Encyclopedia of Religion. New York: Macmillan Publications Company.

Hart, M. (2006). Senarai 100 Tokoh Yang Paling terpengaruh Dalam Sejarah. Kuala Lumpur: Golden Books Centre Snd Bhd.

Kamilah, M. (2013). Meditasi Dalam Agama Buddha. Jakarta: Universitas Islam Negri Syarif Hidayatullah.

Hart, M. (2006). Senarai 100 Tokoh Yang Paling terpengaruh Dalam Sejarah. Kuala Lumpur: Golden Books Centre Snd Bhd.

Ismail, M. Y. (1990). Buddhism Among the Siameseof kelantan: Minority Religion in a Muslim State. Jurnal Antropologi dan Sosiologi, (18: 55-69).

Mokhtar, M. K. (1995). Karya Darma: Kemanusiaan dalam Pembangunan. Selangor: Universiti Kebangsaan Malaysia.

Disputhera, O. (2004). Meditasi II, PendidikanTinggi Agama Buddha. Jakarta: Vajra Dharma Nusantara.

Masefield, P. (2008). Divine Revelation in Pali Buddhism. USA: Rotledge Library Editions: Buddhism.

Russell, P. (2002). The TM Technque: An Introduction to Transcendent Meditation and the teachings of Maharishi Mahesh Yogi. United Kingdom: Elf Rock Productions.

Waramuni, R. (1980). Bayna al-Būdhiah Wa al-Nașrāniyyah Fì Ra'yinā. Bangkok: Bankhar Publications.

Majumda, R. C. (1974). Ancient India. New Delhi: Motilal Bonarsidas.

Kwee. T. H. (2006). Buddha: The Concept. USA: The Michigan University.

Blake, T. (2012). Everyday Meditation: 100 Daily Meditations for Health, Stress Relief and Everyday Joy. Colifornia: New World Library.

Raja, S. S. \& Letchumanan, A. (2005). Tamadun Dunia. Selangor: Fajar Bakti Snd. Bhd.

Rahula, W. (1959). What The Buddha Taught. Finland: Gordon Fraser Gallery Limited.

Antasara, W. (1981). Al-Mabādī' al-Hāmmah Fī al-Būdhiah. Bangkok: Bankhar Publications. 